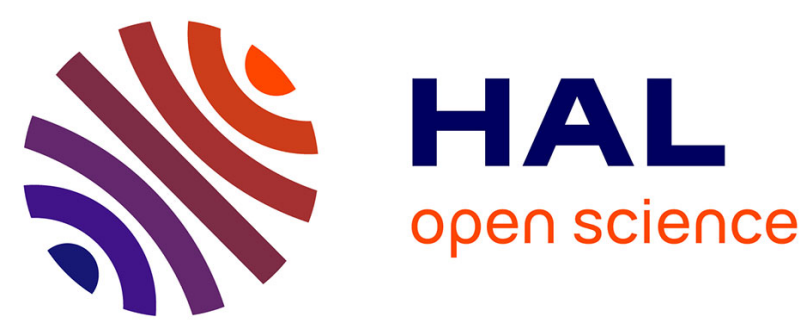

\title{
Influence of laser surface remelt on high temperature oxidation of a low pressure plasma sprayed AMDRY997 overlay coating
}

Weitao Wu, Roland Streiff, Jianqing Zhang, Suqing Xu, Caoliu Zeng

\section{- To cite this version:}

Weitao Wu, Roland Streiff, Jianqing Zhang, Suqing Xu, Caoliu Zeng. Influence of laser surface remelt on high temperature oxidation of a low pressure plasma sprayed AMDRY997 overlay coating. Journal de Physique IV Proceedings, 1993, 03 (C9), pp.C9-607-C9-614. 10.1051/jp4:1993964 jpa-00252404

\section{HAL Id: jpa-00252404 https://hal.science/jpa-00252404}

Submitted on 1 Jan 1993

HAL is a multi-disciplinary open access archive for the deposit and dissemination of scientific research documents, whether they are published or not. The documents may come from teaching and research institutions in France or abroad, or from public or private research centers.
L'archive ouverte pluridisciplinaire HAL, est destinée au dépôt et à la diffusion de documents scientifiques de niveau recherche, publiés ou non, émanant des établissements d'enseignement et de recherche français ou étrangers, des laboratoires publics ou privés. 


\title{
Influence of laser surface remelt on high temperature oxidation of a low pressure plasma sprayed AMDRY997 overlay coating
}

\author{
Weitao Wu $\left({ }^{1}\right)$, Roland Streiff $\left({ }^{2}\right)$, Jianqing Zhang $\left({ }^{1}\right)$, Suqing $\mathrm{Xu}\left({ }^{1}\right)$ and Caoliu Zeng $\left({ }^{1}\right)$ \\ $\left({ }^{1}\right)$ Corrosion Science Laboratory, Institute of Corrosion and Protection of Metals, Academia \\ Sinica, 110015 Shenyang, China \\ $\left({ }^{2}\right)$ Université de Provence, 13331 Marseille Cedex 3, France
}

\begin{abstract}
An AMDRY997 overlay coating on IN100 superalloy substrate was laser remelted using a solid state YAG laser with power of $20-30$ watts. Oxidation tests at $900-1100^{\circ} \mathrm{C}$ demonstrated that the oxidation resistance of the diffused coatings was significantly enhanced by laser surface remelt. The oxide scales formed on both the diffused and the remelted coatings all exhibit excellent spallation resistance. The oxide scale on the remelted coatings was thinner with better protectiveness and seemed to be high in alumina. The diffused samples had thicker oxide scales and considerable internal oxidation along the inherent pores. Laser modified coatings had microstructures with very fine crystallites, and a rather uniform distribution of active elements. Surface segregation of yttrium on the coating surface, enabled the nucleation and formation of a compact alumina scale.
\end{abstract}

\section{Introduction.}

Plasma spraying has undergone impressive development over the last 30 years for the application of coatings to improve the resistance of materials to high-temperature corrosion and wear [1]. However, one major drawback of this technique is the open and closed porosity in the sprayed coatings, which may be detrimental to their strength and corrosion resistance. Another inconvenience is the lack of adherence of the coating to the substrate. Post-coating heat treatment improves the coating quality, but it has some limitations. For example, it necessitates the heating of the whole work piece, which may not be compatible with the required alloy heat treatment, or it may cause melting of a thin substrate. In order to avoid these harmful effects of bulk heating, lasers, electron beams, induction heating, plasma jets and flame heating have been used to post-heat the coating.

Interest in lasers for materials processing stems from their ability to offer extremely high power densities with precise spatial and temporal control. Laser surface treatment is a kind of rapid melting and solidifying process, which can alter the surface structure and properties of materials, especially the surface sensitive properties such as wear, oxidation and corrosion resistance. It has been reported that laser surface remelted alloys, such as superalloys IN 738 and GH 37, Cr-Ni alloys, Fe-Cr alloys and NiCrAlY alloy, showed considerable enhancement of oxidation and hot corrosion'resistance in comparison to the alloys themselves [2]. Similarly, laser surface remelt also showed obvious improvement of hot corrosion and oxidation performance for the MCrAlY type coatings manufactured by plasma spraying or physical vapour deposition techniques. These improvements resulting from laser surface treatment are caused by microstructural refinement due to rapid solidification, redistribution of active 
elements, formation of a thin oxide scale during laser processing, which maintains adherence during subsequent oxidation, and purification of the treated alloy or coating. Further investigations are needed, particularly, on the surface morphology and microstructure of the laser treated alloys and coatings. In a former paper the microstructural modification and the composition alternation of a low pressure plasma sprayed NiCoCrAlTaY overlay coating on IN100 alloy remelted by a solid state YAG laser was reported [3]. In the present paper, the oxidation behaviour, the changes of the surface morphology and microstructure of the laser treated coatings, in comparison with the coatings without post laser remelt is reported.

\section{Materials and experimental methods.}

2.1 MATERIALS. - Laser remelt of an overlay coating AMDRY997 on an IN100 substrate alloy has been carried out using a solid state YAG laser beam. The melting of the surface was achieved by parallel passes of continuous displacement of the sample with the rate of $10 \mathrm{~mm} \cdot \mathrm{s}^{-1}$ under the laser beam with overlaps of $150 \mu \mathrm{m}$. The melting depth varied from $55 \mu \mathrm{m}$ to $100 \mu \mathrm{m}$ for the coating thickness $90-140 \mu \mathrm{m}$ with power input from 24 to 30 watts. Nominal compositions of substrate and coating alloys are given in table I.

Table I. - Nominal compositions of substrate and coating alloys.

\begin{tabular}{|c|c|c|c|c|c|c|c|c|c|c|c|c|}
\hline & $\mathrm{Ni}$ & $\mathrm{Co}$ & $\mathrm{Cr}$ & $\mathrm{Y}$ & $\mathrm{Ta}$ & $\mathrm{Ti}$ & $\mathrm{Mo}$ & $\mathrm{C}$ & $\mathrm{B}$ & $\mathrm{V}$ & $\mathrm{Zr}$ & $\mathrm{Al}$ \\
\hline IN100 & $\mathrm{Bal}$ & 14.7 & 10.1 & - & - & 5.2 & 2.2 & 0.18 & 0.01 & 0.9 & 0.06 & 5.8 \\
\hline coating & Bal & 23 & 20 & 0.6 & 4 & - & - & - & - & - & - & 8.5 \\
\hline
\end{tabular}

The overlay coating AMDRY997 (100-150 $\mu \mathrm{m}$ thick) was applied on IN100 coupons $20 \mathrm{~mm} \times 10 \mathrm{~mm} \times 1 \mathrm{~mm}$ by low pressure plasma spraying under the following conditions: residual pressure $50 \mathrm{Mbar}$; specimen-torch distance $350 \mathrm{~mm}$; torch intensity $650 \mathrm{~A}$; voltage $70 \mathrm{~V}$; Powder feed rate $30 \mathrm{~g} \cdot \mathrm{min}^{-1}$; argon flow rate $601 . \mathrm{min}^{-1} ; \mathrm{H}_{2}$ flow rate $8.511 . \mathrm{min}^{-1}$; argon carrier flow rate $2.81 \mathrm{l} . \mathrm{min}^{-1}$. The coated specimens were subjected to post-coating diffusion treatment for $1 \mathrm{~h}$ at $1100{ }^{\circ} \mathrm{C}$ in vacuum before laser remelt.

2.2 OXIDATION TESTS. - Oxidation tests with discontinuous weighing every $25 \mathrm{~h}$ were conducted for both the diffused and remelted coatings in air for $250 \mathrm{~h}$ at $900^{\circ} \mathrm{C}, 1000^{\circ} \mathrm{C}$ and $1100^{\circ} \mathrm{C}$.

2.3 OXIDE SCALE MORPHOLOGY AND PHASE IDENTIFICATION. - Morphological observation and phase identification were performed by metallography, scanning electron microscopy, electron microprobe and X-ray diffraction, with associated X-ray photo spectroscopy.

\section{Experimental results.}

3.1 Microstructure Of LPPS COATINGS BEFORE AND AFTER LASER REMELT. - The as sprayed coatings exhibited a simple $\beta-\gamma$ two phase structure with a homogeneous interdiffusion zone at the coating/substrate interface. After one hour post heat treatment at 
$1100^{\circ} \mathrm{C}$ in vacuum, the coatings showed a typical lamellar structure with a dispersion of a $\beta$ phase in the $\gamma$ matrix.

The remelted coating shows principally three concentric zones: an outer narrow monophasic which delimits the melted zone; an intermediate two phase zone with a radial columnar structure and an inner two phase zone with an equiaxial structure with uniform distribution of small grains $(2-3 \mu \mathrm{m})$.

EPMA measurements along an arbitrary direction on the surface of the diffused and along a line perpendicular to laser passes on the remelted surface have been made. The results show that after laser remelt the Y content in the top surface is increased and the Ta content is dropped in comparison with that of the diffused coating.

3.2 PhASE IDENTIFICATION OF OXIDE SCALE. - X-ray diffraction spectra were taken from the surface of the diffused and remelted coatings after oxidation tests for $200 \mathrm{~h}$ at $900{ }^{\circ} \mathrm{C}$, $1000^{\circ} \mathrm{C}$ and $1100^{\circ} \mathrm{C}$. Table II summarises the phases detected by XRD from the surface of the coatings oxidised at different temperatures. The $\gamma, \gamma^{\prime},(\mathrm{Ni}, \mathrm{Co})_{17} \mathrm{Y}_{2}$ and $(\mathrm{Ni}, \mathrm{Co})_{2} \mathrm{Ta}$ phases are located directly beneath the oxide scale in the coatings oxidised at the three temperatures. The oxide scales formed for the remelted coatings are mainly $\mathrm{Al}_{2} \mathrm{O}_{3}$ with a little $\mathrm{Al}_{5} \mathrm{Y}_{3} \mathrm{O}_{12}$. The oxide scales for the diffused coatings are composed of $\mathrm{Al}_{2} \mathrm{O}_{3}$ and spinel (Ni,Co) $\mathrm{Cr}_{2} \mathrm{O}_{4}$ (which was not detected for the sample at $900^{\circ} \mathrm{C}$ ), confirming that the oxide scale is doped by Co ions for the diffused coatings but not for the remelted coatings. It also implies that the yttrium or its oxide segregated on the top surface of the remelted coatings, which may be beneficial for the nucleation of alumina crystallites during oxidation so as to enhance its compactness.

Table II. - Phases detected by XRD in the top surface of coatings oxidised during $200 \mathrm{~h}$.

\begin{tabular}{|c|c|c|c|}
\hline $\begin{array}{l}\text { oxidation } \\
\text { temperature }\end{array}$ & coating & oxide scale & $\begin{array}{c}\text { coating beneath } \\
\text { oxide scale }\end{array}$ \\
\hline $900^{\circ} \mathrm{C}$ & $\begin{array}{l}\text { diffused } \\
\text { remelted }\end{array}$ & $\begin{array}{c}\mathrm{Al}_{2} \mathrm{O}_{3} \\
\mathrm{Al}_{2} \mathrm{O}_{3}, \mathrm{Al}_{5} \mathrm{Y}_{3} \mathrm{O}_{12} \\
\end{array}$ & \multirow{3}{*}{$\begin{array}{c}\gamma, \gamma^{\prime} \\
(\mathrm{Ni}, \mathrm{Co})_{17} \mathrm{Y}_{2} \\
(\mathrm{Ni}, \mathrm{Co})_{2} \mathrm{Ta}\end{array}$} \\
\hline $1000^{\circ} \mathrm{C}$ & $\begin{array}{l}\text { diffused } \\
\text { remelted }\end{array}$ & $\begin{array}{c}\mathrm{Al}_{2} \mathrm{O}_{3},(\mathrm{Ni}, \mathrm{Co}) \mathrm{Cr}_{2} \mathrm{O}_{4} \\
\mathrm{Al}_{2} \mathrm{O}_{3}, \mathrm{Al}_{5} \mathrm{Y}_{3} \mathrm{O}_{12}\end{array}$ & \\
\hline $1000^{\circ} \mathrm{C}$ & $\begin{array}{l}\text { diffused } \\
\text { melted }\end{array}$ & $\begin{array}{c}\mathrm{Al}_{2} \mathrm{O}_{3},(\mathrm{Ni}, \mathrm{Co}) \mathrm{Cr}_{2} \mathrm{O}_{4} \\
\mathrm{Al}_{2} \mathrm{O}_{3}, \mathrm{Al}_{5} \mathrm{Y}_{3} \mathrm{O}_{12}\end{array}$ & \\
\hline
\end{tabular}

3.3 SURFACE COLOUR OF COATINGS. - The surface colour of the coatings oxidised for 250 $\mathrm{h}$ at different temperatures are given in table III.

Table III. - Surface colour of coatings oxidised during $250 \mathrm{~h}$.

\begin{tabular}{|c|c|c|c|}
\hline coating & $900^{\circ} \mathrm{C}$ & $1000^{\circ} \mathrm{C}$ & $1100^{\circ} \mathrm{C}$ \\
\hline $\begin{array}{c}\text { diffused } \\
\text { melted }\end{array}$ & $\begin{array}{c}\text { dark greyish-blue } \\
\text { light grey }\end{array}$ & $\begin{array}{c}\text { greyish-blue } \\
\text { light grey }\end{array}$ & $\begin{array}{c}\text { blue } \\
\text { grey }\end{array}$ \\
\hline
\end{tabular}


The bluish colour for the diffused coatings oxidised at all the test temperatures was due to Co ion doping in the oxide scale. Coatings with post laser treatment were non-bluish in colour, indicating none, or very little Co ion doping.

XPS spectra from oxide scales for both coatings oxidised during $200 \mathrm{~h}$ at $900^{\circ} \mathrm{C}$ and 1100 ${ }^{\circ} \mathrm{C}$ were taken. It was observed that $\mathrm{Ti}$ is clearly not in the top surface for both coatings at all test temperatures. Al2p and Ta4f are clearly seen in all the cases; weak or very weak peaks of Ni2p, Co2p and Cr2p are observed for the diffused coatings tested at the two temperatures, whilst for the remelted coatings only a very weak peak of Ni2p and no clear sign of Co2p and $\mathrm{Cr} 2 \mathrm{p}$ can be identified. This proved the significant doping effect of $\mathrm{Co}, \mathrm{Ni}$ and $\mathrm{Cr}$ in the formed oxides for the diffused coatings, but for the remelted coatings the formation of oxides of $\mathrm{Co}$ and $\mathrm{Cr}$ (in some extent, including $\mathrm{Ni}$ ) are suppressed. The peaks of Y3d for the remelted coatings are sharp and strong, whilst for the diffused samples they are weak and dull.

3.4 SURFACE MORPHOLOGY OF OXIDISED COATINGS. - Figure 1 shows the surface morphology of the two types of coatings oxidised during $200 \mathrm{~h}$ at $900{ }^{\circ} \mathrm{C}$ and $1000^{\circ} \mathrm{C}$. Photos No 1012 and 1002 are taken from the surface of the diffused coating oxidised separately at $900^{\circ} \mathrm{C}$ and $1000^{\circ} \mathrm{C}$. It is seen that the oxide scales consist of rather coarse oxide crystallites, with looser compactness. However, for the remelted coatings No 1022 and No 1013, compact oxide scales with very fine crystallites exist on the surface of coatings. In figure 1, the centre part of the photo No 1022 represents the laser remelted area, and that of No 1013 represents the overlapped area.
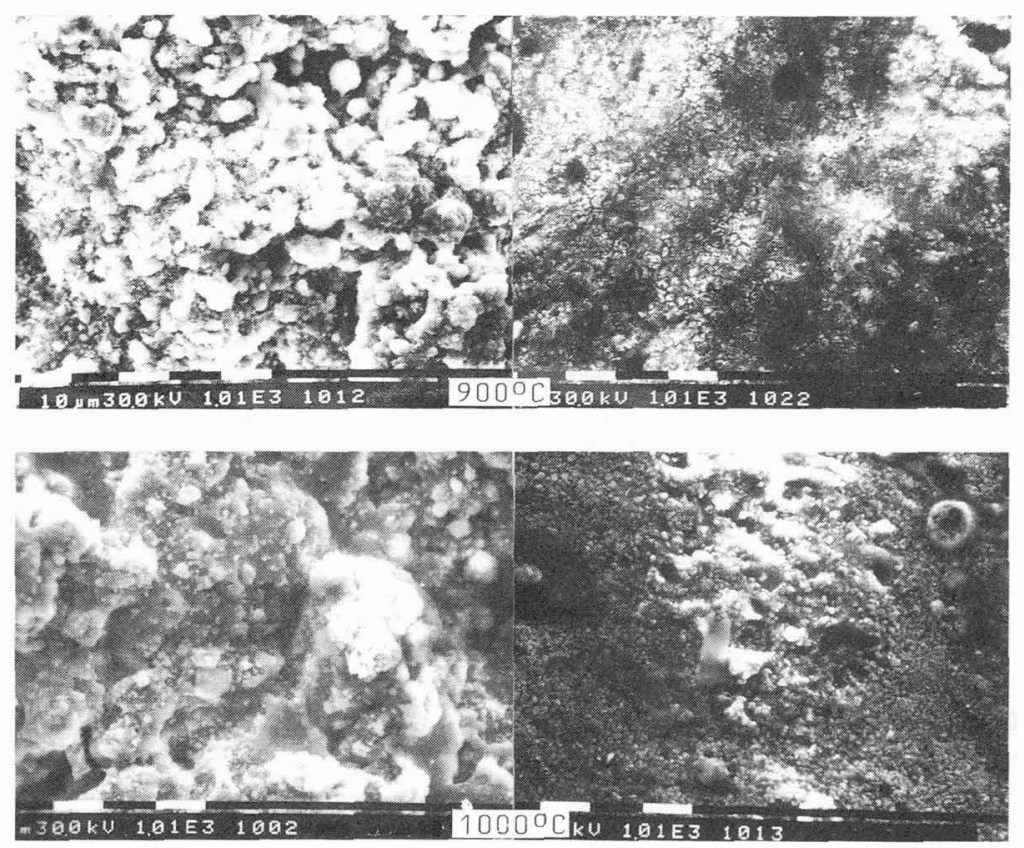

Fig. 1. - Surface morphology of the diffused (Nos. 1012, 1002) and remelted (Nos. 1022, 1013) coatings oxidised during $200 \mathrm{~h}$ at $900^{\circ} \mathrm{C}$ and $1000^{\circ} \mathrm{C}$. 


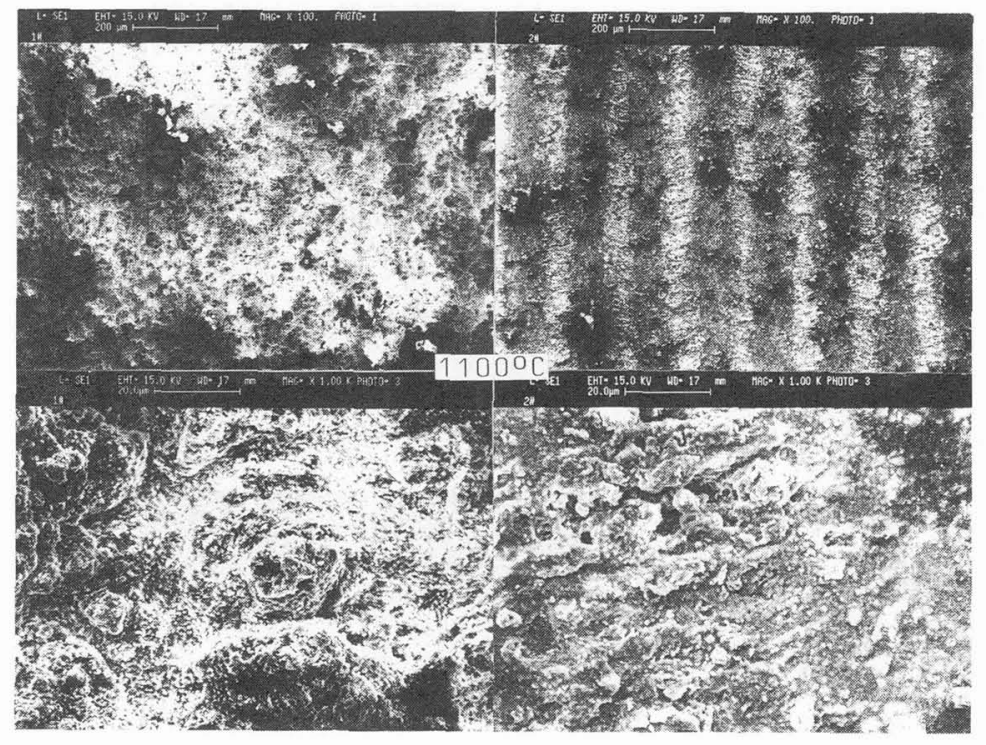

Fig. 2. - Surface morphology of the diffused (No 1-left) and remelted (No 2-right) coatings oxidised during $200 \mathrm{~h}$ at $1100^{\circ} \mathrm{C}$.

Figure 2 shows the surface morphology of the two coatings oxidised at $1100{ }^{\circ} \mathrm{C}$ for 200 $\mathrm{h}$ at low and high magnifications. Again, coarse crystallites can be observed on the diffused coating No 1. Futhermore, at high magnification, loose compactness of the oxide scale is also seen. For the coating with post laser remelting, even after oxidation at $1100{ }^{\circ} \mathrm{C}$ for $200 \mathrm{~h}$, the superficial features of its top surface are maintained; the crystallites grown on both the once remelted and the overlapped area (see top No 2) are very fine and rather uniform. At higher magnification (bottom No 2) the oxide scale on the overlapped track, again shows finer crystallites in comparison to the diffused one (bottom No 1).

3.5 CROSS SECTION OF OXIDISED COATINGS. - The typical cross sections of two coatings oxidised in the temperature range $900-1100^{\circ} \mathrm{C}$ for $200 \mathrm{~h}$ show that the original fine grain coating becomes coarse grain structure with three zones (Fig. 3). The main part of the coating contains large amount of precipitates. The zone directly facing the oxide scale is a narrow layer without precipitates which represents the alloying elements depletion zone; however this zone for the diffused coating is thicker than that for the remelted coating. The zone between main coating part and substrate is an inter-diffusion zone with neither precipitates nor primary carbides; it may be a $\gamma$-phase zone. The thickness of inter-diffusion zone for the remelted sample is also thinner than that of the diffused coating.

Oxide protrusions grow into the substrate for both coatings, but the morphologies were rather different. For the diffused sample some protrusions grow along open pores and some are due to internal oxidation of reactive elements such as yttrium [4]; for the remelted sample protrusions are due to the wavy surface contour formed by laser melting.

Some internal oxidation through open pores was observed for the diffused coating. In some local sites severe undercutting occurred, but not for the remelted sample. Besides, the 

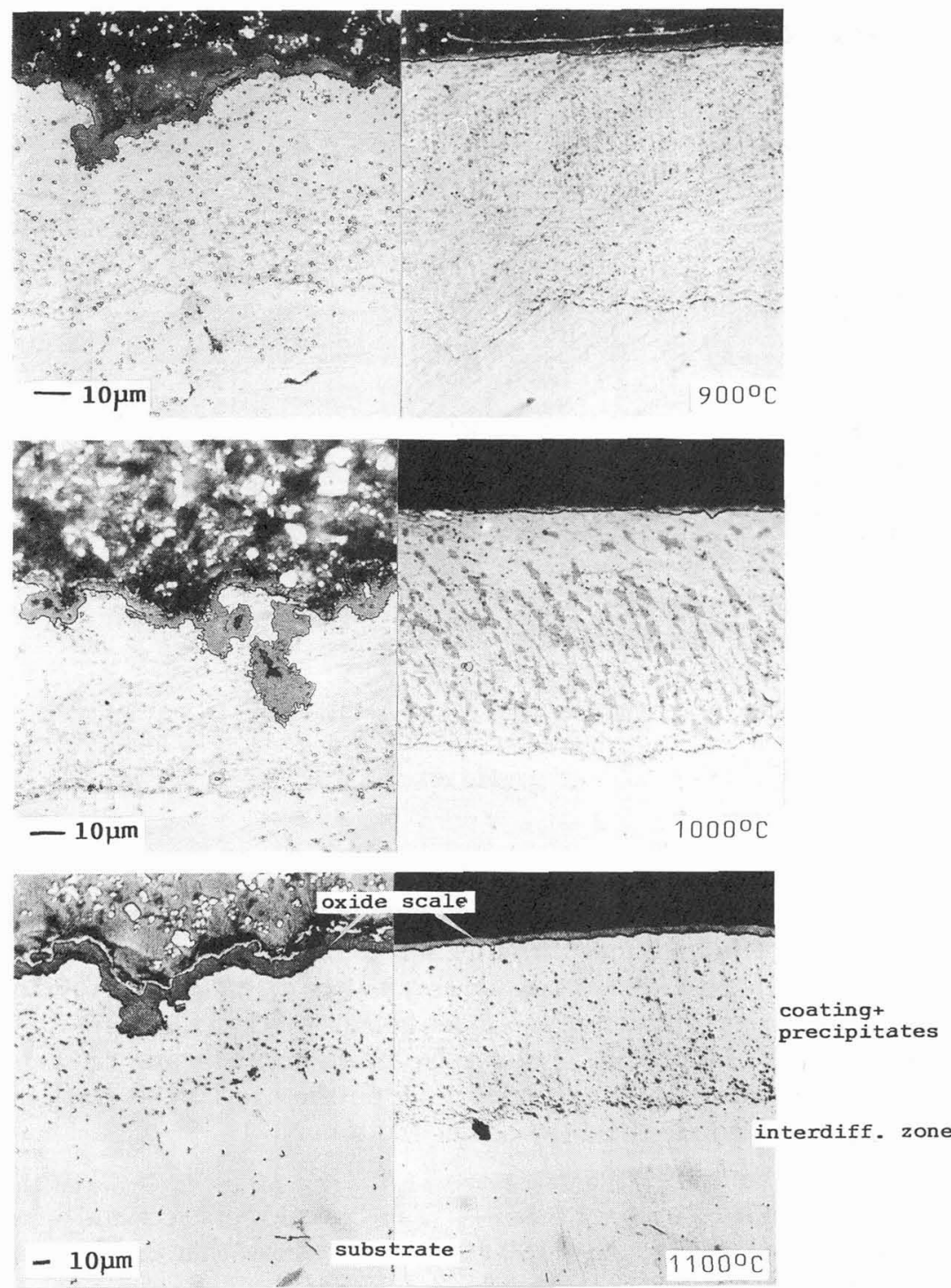

Fig. 3. - Cross section of the diffused (left) and remelted (right) coatings oxidised during $200 \mathrm{~h}$ at $900^{\circ} \mathrm{C}, 1000^{\circ} \mathrm{C}$ and $1100^{\circ} \mathrm{C}$ (coated with $\mathrm{PbO}$, bright field).

thickness of the oxide scale for the former is twofold more than that of the latter. It is worth to note that the oxide formed on the remelted coating is more compact and homogeneous and seems to consist of only one phase, whereas the oxide on the diffused coating is rather inhomogeneous and thicker, consisting of several phases which are somewhat brittle and prone to cracking during metallography preparation.

EPMA quantitative measurements across the coatings oxidised at $1100^{\circ} \mathrm{C}$, shown in the bottom of figure 3 , have been made on the arbitrarily selected precipitates and the matrix near them. On the diffused coating, the main oxide is $\mathrm{Al}_{2} \mathrm{O}_{3}$ but it is observed that some 
islands of $\mathrm{Cr}_{2} \mathrm{O}_{3},(\mathrm{Ni}, \mathrm{Co}) \mathrm{O},(\mathrm{Ni}, \mathrm{Co}) \mathrm{Al}_{2} \mathrm{O}_{3}, \mathrm{Ta}_{2} \mathrm{O}_{5}$ and $\mathrm{Y}_{2} \mathrm{O}_{3}$ occur randomly in the thick oxide scale, whereas, the measurements along the scale on the remelted sample show that the oxide is rather pure $\mathrm{Al}_{2} \mathrm{O}_{3}$ with significant amount of $\mathrm{Y}_{2} \mathrm{O}_{3}$, but with $\mathrm{Ni}$, Co and $\mathrm{Cr}$ rarely detected.

The precipitates in the coatings are similar; in the diffused coating they are bigger, whilst smaller in the remelted sample. Some of them are carbide containing high Ta and Ti. The others are intermetallic compounds with $\mathrm{Ni}, \mathrm{Co}, \mathrm{Cr}$ and a significant amount of $\mathrm{Ta}$ and Ti. Their formula seems to be approximately $(\mathrm{Ta}, \mathrm{Ti})(\mathrm{Ni}, \mathrm{Co}, \mathrm{Cr})_{2}$. In previous studies it was shown that $\mathrm{Ta}$ and $\mathrm{Ti}$ tend to form stable complex carbides [5] or intermetallic compounds. Hence, the outward movement of $\mathrm{Ti}$ and $\mathrm{C}$ during the oxidation process from the substrate to the outer surface is suppressed.

\section{Discussion.}

Extensive internal oxidation through open porosity or defects going into the coating with some severe undercutting occurred in the diffused coatings. A post coating laser melting has been shown to be an invaluable way to eliminate the residual porosity or defects in the coating to avoid internal oxidation.

For the case of a cast alloy [6] laser remelting on the top surface of the coating results in a very fine grain structure with homogeneous distribution of reactive elements $\mathrm{Al}$ and $\mathrm{Cr}$ in the $\beta$ and $\gamma$ phases. This ensures the supply of reactive elements to the oxidation site and formation of pure alumina. The large amount of very fine $\gamma$ and $\beta$ phases with nearly the same level of reactive elements homogeneously distributed acts as oxide nucleation sites for a fine grain alumina oxide at the surface of the remelted coatings. Post coating heat treatment of the diffused coating forms a coarse grain structure and the element contents in $\beta$ and $\gamma$ phases are thus significantly different. This results in an oxide scale of coarse crystallites with rather inhomogeneous chemical composition.

In recent papers $[7,8]$ it was reported that rare earth oxides applied onto the surface of a chromia former alloy help the formation of chromia scale through such effect as the nucleation of the oxide which blocks short-circuit diffusion paths, by segregating reactive element ion, and by the reduction of the stresses in the scale. In a similar manner, as shown here, laser remelt raises the yttrium content as oxide on the top surface of the coating, thus also playing a beneficial role in the selective formation of a thin and compact alumina scale with good adherence to the coating.

Precipitates of carbide and intermetallic compound in the oxidised coating demonstrated that Ta ties up $\mathrm{Ti}$ and $\mathrm{C}$, which come from the substrate and are thought to be harmful to the forming of alumina scale, so that diffusion of $\mathrm{Ti}$ to the surface is suppressed. Ti is an element with strong affinity for oxygen. When it moves to the gas/coating boundary, $\mathrm{TiO}_{2}$ may form and be incorporated into the oxide scale, resulting in disruption of a compact alumina scale $[9]$.

\section{Conclusions.}

Laser remelting transforms the microstructure of NiCoCrAlYTa coating into a very fine twophase microstructure with rather homogeneous distribution of $\mathrm{Al}$ and $\mathrm{Cr}$ in the remelted regions, and segregation of $\mathrm{Y}$ to its top surface.

Oxidation tests demonstrated that the laser remelted coatings are superior to the diffused coatings in oxidation resistance. Internal oxidation through open pores or defects occurred 
in the diffused coatings, but no internal oxidation was observed for the laser remelted coatings. The oxide scales formed on both coatings all showed excellent resistance to spallation during test or cooling process.

The thicker oxide scale formed on the diffused coatings was multi-phases with protrusions growing into the coating. In comparison, the remelted coatings had a thinner and more compact alumina oxide scale.

\section{Acknowledgements.}

This study was made possible thanks to the supply of the coated samples by the company HEURCHROME (Saint Ouen l'Aumône). Thanks also are due to Dr. M. Pons from S2MC (Grenoble) who has perfected the laser remelting of the samples.

\section{References}

[1] SMITH R.W., NORAK R., Powder Metall. Int. 23 (1991) 147.

[2] WU W., STREIFF R., WANG M., High Temperature Corrosion 2, R. Streiff, J. Stringer, R.C. Krutenat Eds. (Elsevier Science Publ., Barking, U.K., 1989) pp. 499-507; Mat. Sci. Eng. A121 (1989) 499-507.

[3] Streiff R., PONS M. and Mazars P., Surf. Coat. Technol. 32 (1987) 85.

[4] WU W., STreiff R., ZhanG J., XU S., LuI G., Proc. International Symposium on High Temperature Corrosion and Protection (Shenyang, China, June 1990) H. Guan, W. Wu, J. Shen, T. Li Eds. (Liaoning Science and Technology Pub, PRC, 1991) pp. 337343.

[5] Huntz A.M., Boumaza A., Moulin G., Lebrun J.L., Proc. of 10th ICMC (Madras, India, 1987) pp. 3565-3576.

[6] WANG M., JIN Z., WU W., Mater. Sci. Eng. 92 (1987) 145.

[7] MOON D.P., BENNET M.J., Mater. Sci. Forum 43 (1989) 269.

[8] STRINGER J., High Temperature Corrosion 2, R. Streiff, J. Stringer, R.G. Krutenat Eds. (Elsevier Science Publ., Barking, U.K., 1989) pp. 129-137; Mat. Sci. Eng. A121 (1989) 129-137.

[9] N'GANDU MUAmba M.J., STREIFF R. (this conference). 